Alejandra Bronfman

\title{
Radio Wars and Revolution in the Caribbean, 1959
}

\begin{abstract}
For most places in the Caribbean, the term Cold War fails to describe the contentious, noisy, violent politics of the I950s and '60s. In the rapidly changing political contexts of I957-62, Haiti's Francois Duvalier and Cuban Fidel Castro rose to power, while in the Dominican Republic Rafael Trujillo's regime weakened and ended with his assassination in I96r. Actors across the ideological spectrum engaged in transnational 'Radio Wars' in their efforts to both undermine and prop up particular regimes. This article will explore those radio wars, understanding them not just as an enactment of the complex politics of the day, but also as the expression of a particular kind of utopian imagining of radio's potential for political mobilisation. It considers the politics of clandestine broadcasting across ideological, racial and national boundaries in the I950s and 'Gos Caribbean. Expanding on and engaging a burgeoning literature on radio in Latin America and the Caribbean, attention to 'Radio Wars' adds fresh perspectives to histories of the Cold War, decolonisation, and the soundscapes of dictatorship and empire. More precisely, it moves beyond a Soviet-US binary and considers the role of broadcasting and propaganda in the making of an inter-Caribbean war of frequencies.
\end{abstract}

KeYwords: Broadcasting, Cold War, Cuba, Haiti, Caribbean

In a recent article, Kate Lacey observes: 'Despite notable exceptions, the volume and scope of the national broadcasting histories are freighted heavily towards the Global North.' ${ }^{\prime}$ Indeed, broadcasting in the Caribbean has not enjoyed the same depth and breadth of study as North American or European broadcasting. Drawing attention to the Caribbean acknowledges the imperial nature of broadcasting from its very inception. Broadcasting stations were established in Cuba and Puerto Rico one year after the first broadcasts in the United States, and they were established as part of a project of capital expansion and investment in that region. In Haiti, they were founded as part of a violent nineteen-year occupation by the US military (I9I5-I934). British broadcasting neglected the U.K.'s Caribbean possessions until a region-wide rebellion in I937 spurred the expansion of radio in the service of civilising through listening. In this region, radio was from its inception imperial and transnational, a feature that could both bolster centres of power and contribute to their undoing. ${ }^{2}$ 
Focusing on empire from the perspective of the margins opens new directions for radio histories. Perhaps because of a defensive posture towards radio as a 'poor cousin' in media studies centred largely on television, cinema, or text, radio historiography generally favours achievements, progress, dissemination and improvement. ${ }^{3}$ The spread of radio, its adoption, the creation of listening audiences, and the making of sonic cultures have been the principal themes of radio history, and rightly so; the dissemination of radio and radio listening as techniques and technologies are crucial to understanding the histories of the twentieth and twenty-first centuries. Yet, our accounts tend to silence the experiments or dead-ends that also shaped broadcasting, often because fragmentary or inconclusive evidence makes it difficult to piece together a seamless narrative. Radio scholars intent on telling stories of success have been less interested in following failed stations or short-lived broadcasting genres. By the same token, our archives are constituted by these silences and replicate them. However, heeding aspects of broadcasting that almost happened or failed to happen will do more than expand the historiography; it may lead it in directions that are more inclusive of marginalised voices and their uses of the medium. It may allow us to listen to the possibility of alternative pasts and refashioned futures. ${ }^{4}$ Attending to the edges and margins offers new ways to comprehend the power and violence that undergirded the creation of certain kinds of radio environments.

One example of efforts shaped with hope but riddled with failure are the attempts to mobilise large groups of people in opposition to a tyrannical regime or dictatorship. In the mid-century Caribbean, political activists frequently turned to radio to activate dissent and generate support for regime change. In I959, taking advantage of the shifting political contexts just after the Cuban revolution, a group of Haitian politicians and activists broadcast their opposition to Francois Duvalier, who had come to power in 1957 and governed with increasingly repressive tactics. The anti-Duvalier activists used Cuban media infrastructures in transnational broadcasts intended to mobilise opposition and bring about Duvalier's downfall. Understanding this episode requires a transnational methodology that shifts between Cuban, Haitian and US sources. While I am still in search of recordings or transcripts of the actual broadcasts in question, newspapers, memoirs, and government documents verify their existence and trace their fate. These anti-Duvalier broadcasts do not receive much attention in either Cuban or Haitian histories, but contemporary observers noted them in some detail.

I draw from the work of Bernard Diederich, a journalist who lived and worked in the Caribbean during the I950s. Born in New Zealand, he lived for many years in Haiti, where he ran the Haiti Sun and served as a correspondent for AP and other news services. Eventually ousted from Haiti by Francois Duvalier, he authored numerous books on the regime and its aftermath, and was attentive to Duvalier's opponents, including the dissident broadcasters. In addition, I draw from Cuban, Jamaican, and US newspapers, Haitian accounts and published sources, and US government documents. In particular, the US State Department compiled reports from unnamed sources on opponents to Duvalier's regime. While the reports range from myopic to racist, they attest to the perceived influence of these anti-Duvalier activists. This is an admittedly imperfect archive, due to the clandestine nature of anti-Duvalier operations and the interest the actors may have had in not preserving sources. Nonetheless, even in fragments 
the story reveals much about transnational broadcasting in the revolutionary Caribbean, and will hopefully prompt further research. I pay attention to hearsay, rumour, and 'intelligence' and ground them in social and political contexts. In particular, I tease out the media environments these political activists inhabited and moved between, and move from individual to state level scales of analysis. There is a measure of speculation, but radio histories may be robust enough by now to withstand some speculation.

\section{The setting}

The years between 1957 and 1962 witnessed the swift and dramatic rise and fall of Caribbean governments. Haiti's Francois Duvalier prevailed in a political struggle in I957 and initiated a decades-long authoritarian regime. Embarking on what would become the Cuban Revolution, Fidel Castro's rebel groups forced Fulgencio Batista to flee the country on New Year's Eve, I958. In the Dominican Republic, thirty years of Rafael Trujillo's dictatorship ended with growing discontent and his eventual assassination in May of 196r. Politics was, in this moment, contentious and dramatic. It was also very noisy. During I959 especially, journalists dubbed the factional battles the 'Caribbean Radio Wars' as they tuned in and tried to make sense of the quickly shifting alliances and animosities, and worked to pinpoint the origins of oppositional broadcasts. ${ }^{5}$ Radio in the I950s Caribbean was already a well-established medium for entertainment, music, and news. ${ }^{6}$ Less well known is its role as a transnational instrument of political struggle. The urgent denunciations of dictators, intimate accounts of battles and struggles and calls reaching across borders to join mobilisations and political struggles were frequently interspersed among the steady stream of ads, broadcasts of baseball and cricket, or the sounds of mambo, konpa or merengue that filled the programs of dozens of radio stations that reverberated throughout the region. Adding to the noise, state-run stations denounced the opposition and stoked the 'radio wars.' Dissidents and the regimes they opposed used radio to stake political ground and mobilise supporters, both within and across their borders.

Some of these broadcasts originated in Havana's well-developed media infrastructure. As early as January I0, I959, a group of Haitian dissidents in exile settled in both Brooklyn and Havana, joined forces, and began a series of creole broadcasts from Havana's Radio Progreso with the aim of mobilising anti-Duvalier sentiment. Those broadcasts reportedly reached thousands of listeners before they came to an abrupt end four months later. It is worth pausing over this neglected incident to consider the ways these dissidents experimented with radio. How effectively could they mobilise populations both local and abroad? Was it possible to succeed with a broadcast that was out of sync with regular programming that did not come with the trappings of an announcer, advertising, the beginning, middle, and end that listeners had come to expect? To what extent did the existence of these broadcasts, regardless of their audience, shape the relationship between the powerful regimes of both Fidel Castro and Francois Duvalier?

Political broadcasting intended to stir oppositional sentiment was, during this period, a common if risky way to practice politics. The broadcasts were not necessarily lengthy, 
or regularly scheduled. The audience was intentionally imagined as distant, and since much of this was from clandestine or hidden stations, there was little possibility of public advertising, or feedback. To send deliberately provocative messages laced with dissent and critique of powerful leaders was to risk either getting no attention at all, or a punitive reaction. Yet, as press accounts suggest, it was widely deployed as a political strategy. As opposed to written text, radio can, and indeed must, be produced and consumed at the same time. Its power and its weakness lies in the fact that it does not have a shelf life. It seems more than a coincidence that Franz Fanon wrote so compellingly about radio's role in the Algerian revolution in I959, noting that people listening were 'motivated not just by eagerness to hear the news, but more particularly (...) to repeat the grandeur of the epic being accomplished up there among the rocks.'7 Despite Fanon's framing of radio as essential to revolution, the medium remains understudied with regards to modes of decolonisation that characterised the post-war years, as scholars usually look to texts rather than considering other media. ${ }^{8}$ Moreover, thinking of the radio as an instrument of decolonisation points to a prevailing mood of hope and internationalism within the Global South as counter to the fear mongering that saturated Cold War airwaves. 9

\section{Voices from Havana}

Haitian politicians Daniel Fignolé and Louis Déjoie led the anti-Duvalier efforts in Havana at the onset of the Cuban Revolution. Fignole had been a union leader and director of Haiti's Mouvement Ouvrier Paysan, a worker's organisation, during the I940s and '50s. A populist known for his powerful oratory skills, he had a large following and served as president for a brief nineteen days in the spring of I957 before a military coup against him prompted his exile to New York City. About his voice, his biographer wrote: 'It menaces. It charms. The people, like duped infants, absorb this new evangelist and his tumult of eloquence that makes them see another vision of the world, of themselves, and of the future.' ${ }^{\text {Io }}$ In the years leading up to his election, he had used this voice, both on the radio and in the street, to successfully mobilise his followers.

Louise Déjoie was a wealthy industrialist who was more conservative than Fignolé, and had opposed him in the I957 election. Déjoie was briefly imprisoned after Duvalier rose to power. When he was pardoned, he made his way to Havana, where he began working with Fignolé and other exiles. Although they did not necessarily concur on ideological issues, they united in their desire to oust Duvalier. Newly revolutionary Havana must have seemed welcoming both in its stated hostility to dictatorships and in its sophisticated media infrastructure.

Cuba's mid-century media environment was rich and voluble. Decades of intertwined radio and politics had created attentive and savvy audiences. Clandestine broadcasting had long been part of the Cuban mediascape, as stations joined in the struggles against President Gerardo Machado in the I930s. Oppositional groups had more publicly taken to the airwaves throughout the I950s. More broadly, radio had been part of everyday life since the late I920s, supported through a commercial model, soon ubiquitous throughout the island, and generating both producers and consumers of news, music, and drama. The sophistication of Cuba's infrastructure, 
the technology, and the personnel, including a deep roster of radio personalities, well-built studios and successful writers and advertisers has led Yeidy Rivero argue that Cuba's broadcasting infrastructures rendered it a 'media empire' during this period. ${ }^{\text {II }}$

The most immediate precedent for broadcasting in the service of regime change was the Cuban revolution's own Radio Rebelde, which was established in I958, allegedly on the insistence of rebel leader Che Guevara, who understood that the way to reach both 'la razon y los sentimientos del pueblo' (the reason and sentiments of the people) was via radio. ${ }^{\mathrm{I} 2}$ Radio Rebelde bolstered Fidel Castro's support as he fought Fulgencio Batista's dictatorship. The broadcasts challenged official versions of the news, and offered intimate behind-the-scenes moments with rebels and the blow-by-blow accounts of battles that conjured a fighting force and a loyal public simultaneously. These broadcasts worked on a transnational level as well. The short wave transmissions had a broad reach, and rebel groups and the general public began to tune in, in Venezuela, Colombia, and Ecuador. As well, stations in those countries would record and then re-broadcast the programs. At times, those rebroadcasts from abroad were more effectively captured within Cuba than the original broadcasts. ${ }^{13}$ Tom McEnaney writes about the ways that Radio Rebelde replaced the radionovela with its own fiery rhetoric and impassioned calls to revolution. It also, he points out, both exploited and eventually bypassed the infrastructures that were in place, built by decades of capitalist interest and transnational business proceedings. ${ }^{\mathrm{I}}$

So in I959, as 'Haitian exiles flocked to Havana' they found a welcoming technological and ideological climate. ${ }^{15}$ Early on, Castro determined to combat Duvalier, whose recent reconciliation with the Dominican Republic's Rafael Trujillo aligned him, in Castro's eyes, with Trujillo's pro-Batista actions and general authoritarian proclivities. Thus, anti-Duvalier Haitians would have sought Cuba's new revolutionary climate as a source of potential allies and support. Fignolé himself had written about a long history of Cuban and Haitian friendship and alliances in anti-slavery and anti-imperial movements, and may have seized the moment as one of a potential opening for the renewal of these coalitions as part of the effort to combat Duvalier. ${ }^{16}$

From Brookyn, Fignolé allegedly recorded programs and sent them to Havana (just after the revolution US-Cuba traffic continued as usual) for the broadcasts. This would have been possible in part because recording technology changed in the I95Os to allow for longer recordings and more audible fidelity to individual voices. ${ }^{17}$ These broadcasts found a home in Radio Progreso, a well-established station that had been founded in 1929 and hosted beloved Cuban bands such as Sonora Matancera and singers including Barbarito Diez. It steadily increased its audiences with radio drama and variety shows, and broadcast its programming over loudspeakers in the midst of middle-class Havana neighbourhood Vedado's rush hours. It joined the national chain of radio stations in the late I940s and sustained its popularity through the revolution, eventually nationalised in $196 \mathrm{I}^{\mathrm{I}}{ }^{8}$ The station had formed a relationship with the Haitian band Jazz des Jeunes and had hosted them in 195I. The dissidents' anti-Duvalier broadcasts, three times a week, spoke to a well-established Cuban audience, but it is difficult to ascertain the extent to which they reached their targeted audience: Haitians in Cuba or even in Haiti, driven by the same desire to oppose and overthrow Duvalier. 
Right away, the press made note of these broadcasts and speculated as to their intentions and audiences. Unsurprisingly, there was not a lot of agreement as to the nature of the programs or the extent of the larger operation - if there was one - of which they were part. Rumours and analyses asserted that people in Haiti as well as the sizable Haitian population in Cuba supported these anti-Duvalier activities. Jamaica's Daily Gleaner, for example, noted that the politicians had 'already begun clandestine broadcasting, warning Haiti's 4,000,000 Negro inhabitants to be ready at moment's notice to put down their tools and launch a general strike against strongman Duvalier.' 19 In February, the New York Times noted that of the thousands of Haitians in Cuba, several hundred were said to support Déjoie and Fignolé. It went on to note the support of Castro, who had been 'making available the facilities of Radio Progreso, from which broadcasts are directed at Haiti to stir up this following. ${ }^{20}$ Ruby Hart Phillips, who had a long history of reporting from Cuba, also offered her version of the movement: she noted that the 'Committee for Liberation of Haiti issued a call today to 'all revolutionary sectors and the citizenry in general' to aid in the overthrow of the Haitian government.' According to her, the broadcasts were in French, twice a week, and aimed at Haiti, and perhaps at Haitians in Cuba. However, her details are fuzzy; she could not say whether Haitians in Cuba were being organised as a fighting force, nor did she provide any details about the broadcasts themselves. She did note that they were threatening enough to provoke an assassination attempt against Déjoie along with other Haitian leaders in exile.

US officials also paid attention to the broadcasts. An interagency report that circulated in the early ig6os noted that Déjoie 'was reported to be making propaganda broadcasts over Radio Progreso which the Haitian government was not completely successful in jamming. ${ }^{22}$ Fignolé, whom the report described as a 'some-time rabble rouser', was also remembered as having 'made a tape recording, which was broadcast to the Haitian people over Radio Progreso in Havana, urging his followers to join with supporters of Louis Déjoie and Clement Jumelle against the Duvalier government, and stand ready for a general strike. ${ }^{23}$ As to the content of these broadcasts, little description remains. It is possible from the descriptions to discern a sense of their affective power: they were laced with attacks on Duvalier, and they communicated a sense of urgency, though they may or may not have contained specific instructions in preparation for a strike or overthrow. Regardless, they did add a new and loud voice to a mediascape that had been recently restricted to Duvalier's voice alone.

\section{Duvalier's battles}

Duvalier had countered hostile broadcasts in the past. Not long after he was elected in I957, rapidly shifting alliances and enmities sounded across national boundaries, as opponents sought to interfere with and destabilise his regime. Bernard Diederich, a journalist who remained in the region for many years, recalled the complexity of radio battles in his book, Papa Doc: The Truth About Haiti Today. In spring of 1958 a series of broadcasts on La Voz Dominicana, President Trujillo's powerful station in the Dominican Republic, denounced Duvalier in Kreyòl, and suggested that his government was full of Communists and posed a 
threat to the Dominican Republic. ${ }^{24}$ To further aggravate Duvalier, the Dominican station announced a clandestine station operating within Haiti and urged Haitians to tune in. Duvalier was particularly enervated to learn that this station was broadcasting from near the Palace (and seat of government), but he failed to identify its precise location despite help from US military personnel. According to Diederich, a Cuban Castro sympathiser and coordinator of the M-26-7 in Haiti, Antonio Rodriguez, ran the station. ${ }^{25}$ Duvalier responded by creating his own station, The Voice of the Duvalierist Revolution, whose sole purpose, according to Michel-Rolph Trouillot, was 'bombarding the public with radio programs extolling the virtues of "The Leader". ${ }^{26}$ More broadly, this station emerged in a context in which the Duvalier regime passed legislation that outlawed any form of political expression, including written, visual, and sonic. This definitively muzzled the press, which until then was a vibrant and critical sector of Haitian society. ${ }^{27}$

The Dominican broadcasts may have been part of what spurred Duvalier, in recognition of the fragility of his position, to begin manoeuvring to secure support or at least neutrality from his closest neighbour. He and Trujillo meet in December 1958 to agree 'not to tolerate subversive activities of political exiles whose actions prejudice good relations between the states.' They also agreed to consult one another in their dealings with the United Nations and Organization of American States, in an effort to practice 'interamerican solidarity'. ${ }^{28}$ As soon as control of Cuba passed into Castro's hands, Duvalier understood the need to maintain his position and moved to secure that neighbourly relationship as well. Very early in I959, Duvalier understood the potential threat the Cuban Revolution posed for him, and he worked to make a good impression by recognising Castro's government on January 8, I959. At the same time, he made a case to the US that Castro's support of hostile Haitian exiles warranted American protection of his regime.

By February, Duvalier managed to persuade the US that Déjoie's anti-Duvalier broadcasts emanating from Cuba constituted enough of a threat to merit their support. The US began a series of loans and payments to alleviate Haiti's budget deficit, working with the assumption that it was best to support Duvalier, because although Duvalier 'has many faults (...) he is not a dictator of the same stripe as Generalissimo Trujillo.' While distaste for Duvalier was palpable at this point, the US was working to prevent what they surmised was Castro's grand plan: to create instability in Haiti, and then use it as a launching pad to overthrow Trujillo. ${ }^{29}$ Duvalier had gained the upper hand: he had simultaneously appeased Trujillo, approached Castro, and procured US aid. Moreover, he at least temporarily gained control of the political soundscape. Very soon after the Radio Progreso broadcasts had served as leverage for US support, they were abruptly and somewhat mysteriously terminated. While Castro was touring Harlem and speaking at Ivy League Schools in spring of I959, Radio Progreso silenced the Haitian programs, and Déjoie left Cuba in May I959. He and Fignolé resurfaced in New York, and then in Puerto Rico, but the Cuban broadcasts were never reinstated.

\section{An uneasy coexistence}

What accounts for this sudden turn in which Haitian exiles no longer found a sympathetic home in Havana? Perhaps it was not so much of a turn. Despite the early reconciliation, 
relations between Haiti and Cuba had grown more uneasy in the first months of I959. Castro had been criticised for supporting and training anti-Duvalier activists on Cuban territory, and he began to distance himself from those efforts. Working on projecting an image of himself as a democratic force in the region, Castro had criticised Trujillo and Duvalier in speeches, but had denied support for armed rebellion. In preparation for his memorable spring tour of the United States, he seems to have worked to present himself as a nationalist more concerned with the fate of his own people rather than exporting revolution. ${ }^{\circ}$ By April, Castro and Duvalier appeared to be breaking ties. Yet behind the scenes, they maintained a consulate in Santiago, and the broadcasts may have been sacrificed as part of a truce that was brokered to both Duvalier and Castro's advantage. Duvalier finally rid himself of the vexing broadcasts, and Castro could deny that he supported the trouble-making Haitian exiles. Intriguingly, when Déjoie left Havana he shared his theory about the paradoxical and seemingly abrupt change of fortune for the broadcasters and their anti-Duvalierist aims. His claim was that Duvalier and Castro had made a deal, in which Castro would rescind support for Haitian exiles, while Duvalier would allow alleged communists from Cuba to infiltrate Haiti. In repressing their activities, Duvalier would fulfil the US's demand that he demonstrate his anti-communism, and continue to garner US support. $3^{\text {I }}$ Historians have largely ignored this intriguing if somewhat unlikely theory, which awaits further exploration.

While the details are vague, it is clear that this incident seems to have brokered the long, somewhat mysterious relationship between the two regimes. As neighbours, Castro and Duvalier ran ideologically opposed authoritarian governments for decades. This remains an understudied phenomenon, overlooked in Cold War histories centred on the US/Soviet Union rivalry. The interlude of the radio wars may have alerted both Duvalier and Castro to radio's disruptive potential and they may have agreed that it posed enough of a threat that its elimination required a wary agreement to repress cross-border dissent. When Castro silenced the broadcasts, he implicitly struck a compromise to let things stand with regards to the closest neighbours while focusing on 'exporting revolution' to the further away Latin American countries. The anti-Duvalier dissidents who had looked to Havana through the romantic lens of revolutionary rhetoric failed to see that they would be cast aside as the revolution maneuvered to remain afloat. It was the failed project of these Haitian dissidents, I suggest, that laid the grounds for Cuba to take its revolutionary ideals further afield, and that cemented decades of an uneasy co-existence between Castro's communist revolution and Duvalier's kleptocratic dictatorship.

\section{Listening and heeding}

By way of a speculative conclusion, I return briefly to the radio broadcasts to think about the publics they may have conjured. The broadcasts, like any broadcast, needed listeners. In this case, the listening public would have been transnational, political and devoted. Following Kate Lacey, I would argue that these were active listeners who 'listened out' rather than 'listening in.' ${ }^{32}$ That is, listening actively rather than passively, listening for rather than listening to - Lacey argues for thinking of listening as a critical activity rather than as mere consumption. In the 
context of the Caribbean radio wars, listeners would have had to have been active - to get to a radio, to, presumably, listen in secret, to develop the kind of media literacy to understand what was being said, who to believe, when and how to respond, who else might have been listening or not. The kind of auditory culture would have had to have been private (as opposed to the more public listening practices), but also collective, knowledgeable, sceptical, as well as idealistic, spontaneous, and disciplined. 33 This is the case for both Cuba and Haiti, whose citizens had by the I950s built up a sophisticated set of listening tactics and strategies. ${ }^{34}$ The radio wars direct our attention to the existence of a cross-border listening public in the Caribbean. Cubans and Haitians have a long history of listening to one another metaphorically, with regards to labour movements, resistance to dictatorship or exploitation, and the emergence of languages of racial justice. In this instance, they listened literally, and would continue to do so long after the dissident broadcasts were silenced.

Intra-Caribbean dynamics and relationships explored in this article open radio histories to narratives of decolonisation and to the politics of the intra-Caribbean neighbourhood, rather than the US-centred notion of 'the backyard.'35 However, they also give us an understanding of the kinds of listening and speaking that were so crucial to these politics, and to which, for some people, the stakes were of life and death. What is at stake for us should heed what was at stake for them, which was the combatting of anti-democratic regimes by striking a delicate balance between infrastructures already present and clandestine channels and publics, as they made a case for themselves with voice and the possibilities of its amplification.

\section{Notes}

I. Kate Lacey, “Up in the Air? The Matter of Radio Studies," Radio Journal: International Studies in Broadcast \& Audio Media I6, no. 2 (20I8): I09-I26, II4.

2. Alejandra Bronfman, Isles of Noise: Sonic Media in the Caribbean (Chapel Hill: UNC Press, 20I6).

3. Lacey, "Up in the Air," Iog.

4. David Scott, Refashioning Futures: Criticism after Postcoloniality (Princeton: Princeton University Press, I999).

5. Tad Szulc, "Radio War Rages in the Caribbean," New York Times, 9 July I959.

6. Yeidy Rivero, "Havana as a I940s-I950s Latin American Media Capital," Critical Studies in Media Communication 26, no. 3 (2009): 275-293; Reynaldo González, Llorar es un placer (Havana: Editorial Letras Cubanas, 2002); Oscar Luis López, La Radio en Cuba (Havana: Editorial Letras Cubanas, I98I); Jennifer Garcon, Transnational Politics of the Haitian Press, I970-1986, (PhD dissertation, University of Miami, 2018).

7. Franz Fanon, "This is the Voice of Algeria," in A Dying Colonialism, translated by Haakon Chevalier (New York: Grove Press, ig65), 86.

8. There is recent work along these lines, particularly that of Rebecca Scales, Radio and the Politics of Sound in Interwar France (Cambridge, 20I6) and Tom McEnaney, Acoustic Properties: Radio, Narrative and the New Neighborhood of the Americas (Evanston: Northwestern University Press, 20I7) as well as Garcon, Transnational Politics of the Haitian Press.

9. Adom Getachew, Worldmaking after Empire: The Rise and Fall of Self-Determination (Princeton: Princeton University Press, 20I9).

Io. Carlo Désinor, Daniel Fignolé: Un espoir vain (Port-au-Prince: L’Imprimeur II, I986), 33; Matthew Smith, Red Q Black in Haiti: Radicalism, Conflict and Political Change, 1934-1957 (Chapel Hill: UNC Press, 2009).

II. Rivero, "Havana as a I940s-I950s Latin America Media Capital."

I2. Guevara, La Guerra de Guerillas, (Havana: Editorial de Ciencias Sociales, I985), I37-138.

I3. Luis Zaragoza, Voces en las sombras: una historia de las radios clandestinas. (Madrid: Cátedra, 2016), 239. 
I4. McEnaney, Acoustic Properties, I37-I39.

I5. Bernard Diederich and Al Burt, Papa Doc: The Truth about Haiti Today (New York: McGraw Hill, I969), I32.

I6. Daniel Fignolé, Cuba and Haiti Institut Mopique, Cahiers du Mopisme (Port au Prince: Imprimerie Moderne, I949).

I7. Gordon Mumma, Howard Rye, Barry Kernfeld and Chris Sheridan, "Recording," Oxford Music Online, Oxford University Press, published online 2003. https://www.oxfordmusiconline.com/grovemusic/view/Io.I093/ gmo/9781561592630.001.0001/omo-9781561592630-e-2000371600.

I8. http://www.radiocubana.cu/glosario-de-terminos-radiofonicos/3I-historia-de-la-radio-cubana/ efemerides-de-la-familia-radial/797-radio-progreso-institucion-cultural-de-la-radiodifusion-cubana.

I9. “Haiti Exiles Announce Plans to Topple Duvalier," The Daily Gleaner, 5 March I959.

20. "US Fears Chaos in a Haiti Revolt," New York Times, 28 February I959.

2I. "A Revolt in Haiti Urged from Cuba," New York Times, I March I959.

22. "Haitians Who Might Contribute Effectively to a Post-Duvalier Regime," Annex Summary Reports on referenced individuals I962/07; Department of State, John F. Kennedy Library, 20I2-08I-doc3; declassified 2014/06/30, p. 28.

23. "Haitians Who Might Contribute Effectively," 33.

24. Diederich and Burt, Papa Doc: The Truth About Haiti Today, I04-5.

25. Ibid., I3I.

26. Trouillot, Haiti, State against Nation, i6o.

27. Garcon, Transnational Politics of the Haitian Press, 42.

28. Diederich and Burt, Papa Doc,: The Truth About Haiti Today, I30.

29. "US Fears Chaos in a Haiti Revolt," New York Times, 28 February I959.

30. "A Revolt in Haiti Urged from Cuba," New York Times, I March I959.

3I. Diederich and Burt, Papa Doc: The Truth About Haiti Today.

32. Kate Lacey, Listening Publics: The Politics and Experience of Listening in the Media Age (Cambridge University Press, 2013)

33. For discussions of listening in authoritarian and anti-authoritarian contexts, see for example Fanon "The Voice of Algeria," Rebecca Scales, Radio and the Politics of Sound in Interwar France, Nelson Ribeiro, "Using a New Medium for Propaganda: The Role of Transborder Broadcasts During the Spanish Civil War," Media, War and Conflict 7, no. I (20I4): 37-50; Tom McEnaney, Acoustic Properties; Carolyn Birdsall, Nazi Soundscapes: Sound, Technology and Urban Space in Germany, 1933-1945 (Amsterdam: Amsterdam University Press, 20I2); Jennifer Garcon, Transnational Politics of the Haitian Press.

34. Bronfman, Isles of Noise; Gonzalez, Llorar es un placer; McEnaney, Acoustic Properties.

35. McEnaney, Acoustic Properties; Tanya Harmer, Allende's Chile and the Inter-American Cold War (Chapel Hill, University of North Carolina Press, 20II).

\section{Biography}

Alejandra Bronfman is associate professor of Latin American, Caribbean and Latina/o Studies at University at Albany, SUNY. She is the author of Isles of Noise: Sonic Media in the Caribbean (University of North Carolina Press, 20I6), which records unwritten histories of broadcasting and sonic technologies in the early twentieth century. Her current research interests include environmental and material histories of media and transnational clandestine broadcasting networks. 